\title{
KLF7 Promotes Gastric Carcinogenesis Through Regulation of ANTXR I [Corrigendum]
}

Li Y, Wang Q, Wang D, Fu W. Cancer Manag Res. 2021;13:5547-5557.

The authors have advised the affiliation list on page 5547 is incorrect. The correct author list and affiliations are as follows.

Yuanchun $\mathrm{Li}^{1,2, *}$

Qingdong Wang ${ }^{3, *}$

DongWei Wang ${ }^{3}$

Weihua $\mathrm{Fu}^{1}$
${ }^{1}$ Department of General Surgery, Tianjin Medical University General Hospital, Tianjin, People's Republic of China; ${ }^{2}$ Department of General Surgery, The Second Affiliated Hospital of Qiqihar Medical University, Qiqihar, Heilongjiang Province, People's Republic of China; ${ }^{3}$ Department of Anesthesiology, First Affiliated Hospital of Jiamusi University, Jiamusi, Heilongjiang, People's Republic of China

*These authors contributed equally to this work

\section{Publish your work in this journal}

Cancer Management and Research is an international, peer-reviewed open access journal focusing on cancer research and the optimal use of preventative and integrated treatment interventions to achieve improved outcomes, enhanced survival and quality of life for the cancer patient.
The manuscript management system is completely online and includes a very quick and fair peer-review system, which is all easy to use. Visit http://www.dovepress.com/testimonials.php to read real quotes from published authors. 